UDK: 297:341

POSLOVNA EKONOMIJA

BUSINESS ECONOMICS

Godina XII

Originalni naučni rad

Broj 2

Str $34-58$

doi: $10.5937 /$ poseko14-18803

Prof. dr Dragan Golubović ${ }^{1}$

Univerzitet Educons, Sremska Kamenica - Novi Sad,

Fakultet poslovne ekonomije

\title{
THE INFLUENCE OF ISLAM ON INTERNATIONAL LAW: WHAT IS AT STAKE?
}

\begin{abstract}
This paper discusses the relationship between Islam and contemporary international order against the background of its arguably positive influence in shaping the guiding principles of International Law. This discussion serves a broader purpose of discerning reasons as to why calls for radical jihad-which portrays Islam as an outlandish and violent ideology incompatible with the current international order-have nevertheless gained traction in the Middle East and beyond. It is argued that this phenomenon has less to do with the quality of scholarly debate about the issue at hand, although the quality thereof plays an important role in the overall efforts to combat radical jihad. Rather, there are hosts of other factors, the author argues, which have fuelled extremism, including a lack of legitimacy of governments in the Middle East. The paper first outlines rules governing conduct of war and peace in Islam. Thereafter it proceeds with the discussion on the influence of those rules on the development of International Law and order, putting them into historic and evolutionary perspective. This discussion is followed by an analyses of the impact of lack of legitimacy on radicalisation in the Middle East. A summary of major findings, offering a path towards the necessary reforms which would mitigate the foregoing problems, is presented in conclusions.
\end{abstract}

${ }^{1}$ dragan.golubovic@educons.edu.rs 
Key words: Islam, International Law, international order, radical jihad, political legitimacy

\section{INTRODUCTION}

This paper discusses the relationship between Islam and contemporary international order against the background of its arguably positive influence in shaping the guiding principles of International Law. This discussion serves a broader purpose of discerning reasons as to why calls for radical jihad - which portrays Islam as an outlandish and violent ideology incompatible with the current international order-have nevertheless gained traction in the Middle East and beyond. It is argued that this phenomenon has less to do with the quality of scholarly debate about the issue at hand, although the quality thereof plays an important role in the overall efforts to combat radical jihad. Rather, there are hosts of other factors, the author argues, which have fuelled extremism, including a lack of legitimacy of governments in the Middle East. The paper first outlines rules governing conduct of war and peace in Islam. Thereafter it proceeds with the discussion on the influence of those rules on the development of International Law and order, putting them into historic and evolutionary perspective. This discussion is followed by an analyses of the impact of lack of legitimacy on radicalisation in the Middle East. A summary of major findings, offering a path towards the necessary reforms which would mitigate the foregoing problems, is presented in conclusions.

\section{AN OVERVIEW OF RULES GOVERNING WAR AND PEACE IN ISLAM}

The rules governing conduct of war and peace in Islam are to be found in the so called Islamic International Law - Siyar. The term Siyar literally means 'conduct, practice, comportment, behaviour, or acceptable behaviour' (Munir 2007:929). Muslim historians originally used the term with regard to the conduct of Prophet Mohammad in dealing with issues pertinent to war. As Ghazi (1998:3) explains:

The term Siyar indicates that the conduct of the Prophet (peace be on him) in his international dealings constitutes the basis on which the detailed rules of law were developed. He fought battles with his enemies; sent envoys and emissaries and wrote letters to his contemporary rulers; received delegations; led his followers and himself participated in negotiating various treaties and agreements of 
international import, and dealt with the questions of booty, prisoners of war, and acquisition of the enemy property.

The term Sirat (the plural of Siyar) was used by some historians and conservative scholars interchangeably with the term Maghazi (wars). The expression Shari ah Siyar refers to issues pertinent to the law of war and is used inter-changeably with the expressions Kitab al-Jihad and Kitab alSiyar respectively (Munir 2007). While the foregoing may suggest that the Siyar is a concept which is only concerned with the conduct of war (jus bellum) its scope arguably expanded over time. Since the early II century Muslim jurists embraced the term to describe a branch of law governing the conduct of Islamic State towards non-Muslim entities in times of war and peace (Hamidullah 2001). Imam Abu Hanifa is widely credited as the first scholar to have used the term in this respect. He used the term Siyar to title his lectures on Islamic law of war and peace, thus paving the way for its development as a distinct legal discipline. Some of Imam Hanifa's followers and students, including imams Abu-Yusuf and Shaybani, expended on his work and over time the Siyar assumed a notion of Islamic International Law (Ghazi 1998; Munir 2007; Khaldun 2015).

The concept of Siyar was embraced by the Sunni schools of Islam only. Nevertheless, its significance stems from the fact that the Sunni schools of thought 'are much more thoroughly researched and second, the categorization of those rules in the Siyar provides an excellent starting point for a comparison of the Islamic rules with other legal systems like International Law' (Moschtaghi 2009:391). This approach in particular has merit given that the points of perceived convergence between the Shi'a and the Sunni schools of Islam are more significant than their notable differences (Moschtaghi 2009: Bassiouni and Badr 2002; Hourani 2013).

As already noted, since its inception in the early Islam the Siyar stood for a body of knowledge and binding rules covering a wide range of issues, the bulk of which was concerned with the conduct of war. This is attributed to historical reasons i.e. hostilities between the ever expanding Islamic State and non-Muslim entities which spanned over the first three centuries of Islam (Ghazi 1998; Khadduri 1956; Ali and Rehman 2005). Emerging in the VII century of the Christian era (C.E.) as a conquering power set to ultimately rule the world, Islam refused to recognise legal and political systems other than of its own-and was willing to concede to peaceful relations with non-Muslims only as a temporary stage pending the accomplishment of its world mission. Indeed, there is a common thread in this respect between the ancient Rome, the law of medieval Christendom, and Islam in that they were all based on a theory of universal state i.e. the higher nature of one people which sought to stamp their national character 
or religion on the entire world (Khadduri 1956; Hourani 2013; Bluntschli 2000; Said 2003; Phillips 2005; Ahmad 2014). In keeping with this original premise of Islam, classical jurist scholars (hanafi) painted the Manichaean picture of the world being divided into the land of peace (dar al-Islam) and the land of war (dar al-harb). The land of peace (also referred to as the land of Islam) consisted of territories where 'the power lies with Muslims, where the rules of Islam are implemented and Islamic rituals are performed', whereas the land of war consists of territories 'which are outside the scope of Islamic sovereignty and where the religious and political rules of Islam are consequently not implemented; its people are belligerents' (Al-Zuhili 2005:278). In order to establish global peace, Islam must be spread to the dar al-harb. To accomplish that goal, the scholars called for jihad which generally meant any kind of efforts, peaceful or violent, deemed necessary for the Islamic State and faith to prevail. Thus the Muslims were under legal obligation to submit infidels to the rule of Islam, resorting to jihad as a tool of choice. As Khadduri (1956: 359-360) explains:

The jihad may be regarded as an intensive religious propaganda which took the form of a continuous process of warfare, psychological and political, no less than strictly military. From a legal viewpoint it meant a permanent state of war between Islam and enemy territory. But this state of war should not be construed as actual hostilities; it was rather equivalent, in Western legal terminology, to non-recognition.

Following this overall theological and ideological framework the Siyar recognized only Muslims as legal and political subjects, whereas the inhabitants of the dar al-harb were regarded as mere objects with no legal power and the right for political organisation. It should be noted however that a similar approach was embraced by some Christian theological jurists in the early stage of development of International Law, which discriminated against non-Christians (Stumpf 2005). In this respect, some scholars argue that a more precise connotation for the Siyar is an 'external law of Islam', because of its resemblance with the Roman ius gentium i.e. codified domestic rules governing relationship between the Roman citizens and foreigners (Moschtaghi 2009). Regardless of this debate, it is clear that the Siyar does not stand apart from the general Islamic corpus iuris (Shari'a/Shari'ah), but is rather incorporated therein; hence, the same sources (Moschtaghi 2009; Khadduri 1956). While the discussion on the sources of law in Islam has proved to be contentious, there is at least common understanding that the Qur'an and tradition (sunna/sunnah) are primary sources and that consensus (ijma) and analogy (qiyas) are secondary (supplementary) sources of the Shari'a/Siyra (Bassiouni and 
Badr 2002; Khadduri 1956; Hourani 2013; Ali and Rehman 2005). The Qur'an is the controlling source of Shari'a. It spells out Prophet's commands governing all aspects of social and individual life in unequivocal terms, which are presumed to be understood and observed by everybody. The complexity of Shari'a however stems from the fact that the Qur'an is not a legal code. Rather, it is composed of Prophet's revelations (wahy zahir), few of them being explicit legal commands: out of 6,239 verses there are only 500 (often overlapping) verses with legal content (Bassiouni and Badr 2002; Ali 2004; Ibn Khaldun 2015). Chapter 2, verses 190-195, principally governs the conduct of war, in addition to more than 60 other verses pertinent to the issue which are scattered throughout the Qur'an (Bassiouni and Badr 2002; Kamali 2003; Ali (2004; Hourani 2013; Sardar 2015); Ibn Khaldun 2015). Tradition (sunna) is made up of reports (hadith) of the speech and actions of the Prophet and his companions which supplemented the Qur'an. There are altogether 7,275 reports compiled by the jurists (ulama) after the passing of the Prophet. However, because of their repetition and overlaps, this number is actually smaller: 2,762 Most of the rules governing conduct of war were spelled out in the reports stemming from more than twenty battles amid the Prophet's settling in Medina in 622-632 C.E. (Sardar 2015; Ali and Rehman 2005). The Qur'an and the tradition are equally infallible in that neither can abrogate the other. The apparent contradictions can be reconciled between the two, or otherwise a latter verse of the Qur'an or revelations of the Prophet is deemed to abrogate the prior one (Bassiouni and Badr 2002; Hourani 2013). The principle sources of Shari'a/Siyar operate as follows: 'the Qur'an informs the understanding of the sunna; sunna, in turn, determines the scope of consensus; and scholarly consensus (uma) constrains the scope of analogy' (Hourani 2013:67-68).

The secondary sources of Shari'a, (consensus and analogy) were developed out of necessity after the passing of the Prophet (Khadduri 1956; Barnidge 2010; Stumpf 2005). Their significance for the development of Siyar, and more broadly Islamic law, can hardly be overestimated. They facilitated jurists' efforts to interpret the primary source of Islamic law (the Qur'an and the tradition) in keeping with economic and social changes during the golden age of Islamic jurisprudence up to the IX century, and again since the XIX century (infra, Chapter 3). The only constraint on the use of secondary sources and the outcomes resulting from their application is that they cannot contravene a norm or outcome derived from the Qur'an. Given the relatively small number of norms found in the Qur'an and the authenticated reports (hadith) of which the tradition is made, it is argued that the impact of this constraint is limited as compared to the whole body of Islamic law 
(Bassiouni and Badr 2002). Pertinent literature also points to other secondary sources of Siyar including the practice of the early Caliphs, arbitral awards, treaties, and custom (Ghazi 1998; Bassiouni and Badr 2002). Custom is arguably not only a source of both the Siyar and International Law and order, but they also share two critical similarities as regards their constituent elements: the requirements that there must be a prevailing (not necessarily universal) and consistent practice of states over some period of time, and that they must accept that practice as law governing their international relations either explicitly or tacitly (Zahid and Shapiee 2010; Hamidullah 2001)

\section{THE CONTENTIOUS UNIVERSALISM OF RULES GOVERNING WAR AND PEACE IN ISLAM}

As previously discussed, the Siyar was an integral part of Islamic law (Shari'a) which is deeply rooted and inseparable from Islam. Indeed, there are no differences between the Shi'a and the Sunni schools of thoughts when it comes to the supremacy of Shari'a: it is regarded the critical condition for a state to be considered Islamic (Moschtaghi 2009). The underlying reason as to why the Siyar was primarily concerned with the conduct of war was due to the original prophets of Islam. For Islam the lasting peace was only possible with shared belief, the dar-al-Islam, regardless of the means employed to accomplish that goal: there would not be lasting peace until Islam conquered the world and all infidels conformed to it (Moschtaghi 2009). However, the emergence of International Law in XVII century-which is defined as a body of rules established by custom or treaty and recognized by nations as binding in their relations with one another (Jennings, Watts 1992:16), offered a different discourse: rather than from a shared belief, peace among nations needs to be secured by an order which allows different beliefs to co-exist. All nations, regardless of their religious standing, are equal and equally responsible for international order and maintenance of peace. For conservative Islamic scholars, guided by the strict interpretation of Shari'a, this was a challenging proposition. As Westbrook (1992: 828-829) aptly summarized:

Islamic scholars, who locate legal authority with God, cannot so easily separate law and belief. The public International Law solution of order without shared belief is not available to Islamic scholars, insofar as their work is informed by Islam. Still, the solution remains attractive on its merits and because it is the framework used by the non-Islamic world to articulate large-scale political arrangements. 
The outset of XX century saw the split of the Ottoman Empire and proliferation of the Muslim nation states. Regardless of their law of choice (secular law in Turkey or the Shari'a in other Muslim states), they have largely embraced secular approach in their foreign relations and the principles espoused by International Law and order either expressly, tacitly or by customary practice. That despite the fact that the political role of Muslims in the formatting stage of International Law was modest at best given that Turkey, representing Sunni Muslims at large, was admitted to the arena of International Law (at the time called 'European public law') only in 1856 (Zahim and Shapiee 2010; Hourani 2013; Khadduri 1956; Hamidullah 2001). Khadduri argues that even those Islamic scholars who objected to this secularisation trend reconciled with the significant departures from the traditional Siyar and that the large majority of them repudiated the idea of jihad being offensive in character (Khadduri 1956). Some Muslim scholars even content that the Siyar originally espoused the principle of peace among nations, referring to a period before twenty battles the Prophet fought before settling in Medina, during which most of the rules governing conduct of war were developed (supra, Chapter 2.). This view draws on the literal interpretation of jihad which stems from the Arab verb jahada, meaning to struggle or exert, rather than on its popular interpretation as holy war. It also draws on the alleged Prophet's revelations which draw the line between a minor jihad i.e. the extortion of force in battle, and a major jihad, i.e. self-exertion in peaceful and personal compliance with Islam (Khadduri 1956; Ali and Rehman 2005). Others argue that secularization of the traditional Siyar did not give rise to a departure from its underlying principles altogether. Rather, some of them served as an inspiration for the founders of International Law and were duly embedded therein. Thus it is argued that the Muslim's peculiar intellectual orientation, which obliges them to observe certain ethical norms embedded in Islam, rather than to pursue their collective selfinterest freely, was subsequently transposed in International Law and order (Ghazi 1998). To what extent that peculiar intellectual orientation precisely influenced the formatting stage of International Law and order is a matter of an ongoing debate, however. Boisard (1980:430) points to the methodological challenges in this respect, given that 'identical ideas may be generated spontaneously without showing any imprint whatsoever'. Nevertheless, he finds this influence undisputed as it seems impossible that 'the Spanish canon scholars, and Grotius who succeeded them, should not have borrowed anything from the Muslim civilisation in power in the Mediterranean until the end of the sixteenth century' (Boisard 1980:441). He also argues that the first codified volume of laws in Europe, Las Siete Partidas, which was drafted by Alphonese IX in the second half of XIII 
century, borrowed substantially from the Siyar (Boisard 1980). Similarly, Ghazi contends that Muslim jurists were undoubtedly the pioneers in the field of International Law in the sense of an independent legal discipline (Ghazi 1998). Munir recalls that in 1827 Joseph Hammer von Purgstall, a German scholar who reviewed the Turkish translation of the Shaybani book Sharh Kitab al-Siyar al-Kabir, called Shaybani 'the Hugo Grotius of the Muslims', which he finds to be 'a considerable understatement' (Munir 2007:938). He further argues that the understanding of Grotius's underlying principles of International Law, as well as the understanding of some of his predecessors, such as Francisco de Vittoria, was heavily borrowed from or influenced by the Siyar (Munir 2007; Boisard 1980).

Al-Zuhili argues that the three fundamental requirements the Siyar is based upon: necessity, humanity and chivalry, were duly incorporated in the Preamble of the 1899 and 1907 Hague Conventions, which were the first multilateral treaties to address the conduct of war. Those requirements are reflective of a number of specific rules as developed by the Siyar and subsequently enshrined in the four 1949 Geneva Conventions (Convention for the Amelioration of the Conditions of the Wounded and Sick in Armed Forces in the Field, August 12, 1949; Convention for the Amelioration of the Conditions of the Wounded, Sick and Shipwrecked Members of Armed Forces at Sea, Aug. 12, 1949; Convention Relative to Treatment of Prisoners of War, August 12, 1949; and Convention Relative to the Protection of Civilians in Time of War, August 12, 1949) and the first additional Protocol (Protocol Additional to the Geneva Conventions of 12 August 1949, and relating to the Protection of Victims of International Armed Conflicts (Protocol I), 8 June 1977). These rules inter alia include the protection of civilians, the distinction between legitimate military objectives and civilian objects, the prohibition of the killing of priests, women and children, the prohibition of the destruction of property unless there is a military necessity to do so, and the legitimacy of guarantee public or private safety on the battlefield, to prevent as far as possible the continuation of warfare. He discerns further points of convergence in the rules of Siyar governing the prohibition of perfidy, and the human treatment of enemy in the conduct of war, including prohibition of mutilation of bodies and disfigurement, even in cases when enemies practices such acts, the prohibition of starvation, thirst, torture, severe abuses and assault, the prohibition to have his property plundered, in violation of the sanctity of human brotherhood, except when necessity so requires to fend off aggression, and the human treatment of prisoners (AlZuhili 2005), His analyses is seconded by hosts of other authors who find the same or similar points of convergence between the Siyar and international law and order. This also includes the principle of pacta sunt 
servanda i.e. honouring covenants and commitments as long as the other party is faithful to its own pledges (Bennoune 1994; Ali et al 2011; Ali 2010; Munir 2007; Hamidullah 2001; Ghazi 1998; Al-Zuhili 2005; Ali and Rehman 2005; Yousaf 2012; Cockayne 2002: 622, notes 108-120 with additional references).

The positive influence of Islam in shaping International Law and order is also referenced in the 1996 case of Legality of the Threat or Use of Nuclear Weapons before the International Court of Justice In his dissenting opinion Justice Weeramantry notes that the roots of the international humanitarian law are embedded in diverse religious and philosophical ideas, including Islam. He discerns the influence of Islam in the prohibition of the use of poisoned arrows or the application of poison on weapons such as swords or spears, the unnecessarily cruel ways of killing and mutilation, the protection of non-combatants, women and children, monks and places of worship, the human treatment of prisoners, as specifically referenced in the Qur'an, and the prohibition of the destruction of livestock and crops by anyone holding authority over territory. He further notes that Islamic law was so developed with respect to conduct during hostilities that it required not merely that prisoners be well treated, but that their last will made during captivity be conveyed to the enemy through an appropriate channel (Advisory Opinion, 1. C.J. Reports 1996: 226).

As noted (supra, Chapter 2), the Siyar purportedly also covered the law of peace between Muslim and non-Muslim communities, albeit to a lesser extent. It developed rules governing trade treaties, conflict of law rules, choice of law, safe-conduct (aman) of foreigners and traders who temporarily visited Muslim territories, and the status of non-Muslim residents (Ghazi 1988: Zahid and Shapiee 2010; Munir 2007; Khadduri 1956; Hamidullah 2001). Those rules sprung out from the concept of territorial jurisdiction (dar) which is argued to have had far reaching consequences for the development of Siyar - and subsequently for the development of International Law (Ghazi 1988; Khadduri 1956; Marboe 2013; Westbrook 1992). While Islamic law of peace was originally envisaged as a temporary institution governing the relations with nonMuslims in periods of truce, over time jurists began to interpret the Siyar in a fashion which would justify the suspension of radical jihad. One of the reasons for this revisionist interpretation was the fact that Muslims did not always reached truce on their own terms. This eventually led to Muslims being more reconciled with the permanency of law of peace-and willing to embrace alliances with non-Muslim states (Khadduri 1956; Stumpf 2005; Hourani 2013). This genesis prompted some scholars to differentiate between three stages of development of the Siyar: the 'age of expansion' 
when Islam embarked on conquering the world; the 'age of interaction' which saw the main change in legal thought in the rationale for waging war against non-Muslims, in which dichotomy of the dar-al-Islam and the dar-al-harb was replaced by a tripartite division of the world into the daral-Islam, the dar-al-harb and the dar-al-sulh (territory of peace) respectively; and the 'age of coexistence' which coincides roughly with the formative stage of International Law and order, and which continues to date. It is in the third stage that peace treaties between Muslim and nonMuslim states no longer had to be of limited duration, as peace among them was no longer seen as a temporary stage in their relationship (Badr 1982; Bennoure 1994; Ali and Rehman 2005).

Pertinent literature also offers a more sceptical discourse on the influence of the Siyar on International Law and order, ranging from the outright rejection of any non-Christian influence on International Law (Draper 1965; Huntington 1996) to a more subtle criticism of such an influence. As for the latter, Bouzenita notes that because of its peculiar historical development the Siyar lacked the concept of a territorial state, which is one of the distinctive features of International Law and order (Bouzenita 2007). Barnidge cautions that similarities between the Siyar and International Law can only be approximate, given that they root themselves in different contextual languages, which matters. He warns against magical formulas of interpretation in matters of war and peace, and contends that the Islamist understandings of apostasy and the inherent preference of militant Islamists for violence should serve as a cautionary tale for international lawyers. The latter are inclined to think that proclaiming violence as impermissible with Islam should save the posterity from the carnage of war (Barnidge 2010; Hurd 2003). Westbrook too is sceptical of evidence pointing to the influence of Siyar on international law (Westrbook 1992).

Many scholars and clerics-proponents of the concept of radical jihad as an instrument of permanent and all-out war against infidels, also deny the Siyra's influence on, or for that matter compatibility, with International Law and order. Radical Islam rejects the discursive values of International Law altogether and perceives the current international order as a temporary phase towards the eventual forced spreading of Islam on the whole world. This discourse, which is embraced by radical clerics and terrorist groups, and enjoys some level of public support (infra, Chapter 4), draws heavily on the selective reading of the primary sources of Islam (the Qur'an and the tradition, supra, Chapter 2). The theological underpinnings of the concept of radical jihad are summarized by professor Mushkat (1987:227), himself an advocate of the concept: 
Islamic law enjoins Muslims to maintain a State of permanent belligerence with all non-believers, collectively encompassed in the dar al-harb, the domain of war. The Muslims are, therefore, under a legal obligation to reduce non-Muslim communities to Islamic rule in order to achieve Islam's ultimate objective, namely the enforcement of God's law (the Sharia) over the entire world.

At least some of the foregoing arguments against the influence of Islam on International Law and order seem somewhat misplaced, however. As a starting point, the divine (dogmatic) nature of the primary sources of Islamic Law (supra, Chapter 2.) could not have possibly posed an obstacle for import of some of its underlying principles into the body of International Law and order - much the same as the divine character of the other religions, Christianity included, posed no obstacle for their influence on International Law. Indeed, the reluctance of various academic fields (political study, anthropology, International Law) to factor the overall impact of religion on social fabric and public policies has arguably played into the hands of religious extremism (Philpott 2007). Furthermore, some of the arguments denying the influence of Islam appear to be drawn from analogy, rather than historical perspective, or are based on the selective interpretation of the primary sources of Islam. As Cockayne points out, the use of analogy on this particular subject in most cases tends to compare the West and Islam as static and monolithic constructs, and use the former as the major reference point. Instead, a historical perspective on the issue, departing from a different starting point and looking at dynamic interaction between the West and Islam and their contribution to shaping International Law and order on equal par offers a better insight (Cockayne 2002:597 at seq; Cox 2013). In light of this, the argument that Islam could not have influenced the formation of International Law and order, because it did not originally recognize the concept of territorial state, can hardly be taken as a decisive argument in the debate, as it overlooks how it evolved over the period of time. The often cited example of this evaluation is the Treaty of Alliance concluded between Sultan Sulayman the Magnificent and Francis I, King of France and signed in 1535. Originally, the general view of the Muslim scholars was that a permissible period of peace was restricted to a period of up to ten years; this understanding relied on the Treaty of Hubaybia which was made during the lifetime of Prophet. However, Muslim states subsequently accepted extension of the ten-year rule to treaties of unlimited duration (Khadduri 1956; Sardar and Rehman 2005). The Treaty of Alliance was a milestone event in this development in that it brought about significant innovations in the relations between Christian Powers and Islam in early modern times, in keeping with the concept of 
territorial jurisdiction (dar) which over time was developed in Islam (supra). Among others, the Treaty put on equal footing the King of France and his representatives with Sultan Sulayman and his representatives. Thus, Article 1 of the Treaty provided for the establishment of a 'valid and sure peace' between the Sultan and the King 'during their lives', and granted reciprocal rights to the subjects of each monarch in the territory of the other. In addition, the Treaty exempted Christians from the poll tax and granted the Frenchmen right of being tried by their own consulates, thereby modifying traditional rules of the Islam governing those issues (Khadduri 1956:360-362).

The historical perspective in the interpretation of Islam is seconded by those scholars who argue against the traditionalists' approach towards Islam which relies exclusively on the primary sources of Islam as the ultimate expression of the divine will. This approach renders any further refinement of Islam impermissible or indeed impossible. In this respect Badr notes that Islamic law and the Siyar respectively are not parts of the dogma of Islam, but rather the products of continued development by authoritative jurists over the ages. He further notes that Islamic law is a religious law only in a sense that its basic grounds and some of general principles are embedded in the Qur'an and the revelations of the Prophet, and points to the role of secondary sources i.e. contribution of the various schools of jurisprudence in its development (Badr 1982). Similarly, Cox (2013: 308) points that 'the nature of Islamic law means that it is open to a variety of different interpretations',- - and this pertains to all aspects of life as governed by Islam. Thus Ali points to the fact that one of those juristic interpretation techniques Takhayyur - a term used to describe the process of considering possible alternatives from a range of juristic opinions with a view of applying less restrictive rules on the issue at hand, has had significant impact on developing women-friendly family laws in some Muslim countries (Ali 2010). Ali and Rehman note that apart from the Qur'an and the tradition which were inspired by the Prophet, but compiled by human beings after his death, all the other sources of Islam were clearly devised by human knowledge and endeavour. They lament that this inference does not appear to be as obvious as it should be, given that the majority of Muslim scholars still argue that Islam is divine and hence unchangeable. This explains the restrictive interpretation of jihad as an instrument of aggressive war (Ali and Rehman 2005).

In light of the foregoing discussion, whether some of the guiding principles shaping International Law and order can be credited to the influence of Siyar, or whether some of those principles simply overlap, in ultima linea seems secondary. Because the current debate on the issue at hand is largely focused on refuting the extremist views of Islam as not 
compatible with universal values enshrined in International Law and other, either of those premises go to prove to the contrary. More broadly, it is noteworthy that both the term Orient/Islam and the concept of West generally lack any ontological stability and thus are prone to pluralistic and inherently subjective interpretations (Said 2003). This provides additional legitimacy to efforts to dissect points of convergence between Islam and International Law and order. Otherwise, the alternative is for scholars to reconcile with the fallacy of dogmatic Islam which entails that it perceives the current international order as temporary until the whole world submits to it. This discourse ignores the fact that the United Nations Charter allows the use of force only in the limited instances of self-defence or through decisions of the UN Security Council-and that the Muslim states-members of the U.N. recognize the consistency of those principles with Islam. This is clearly manifested in the Preamble of the 1972 Charter of the Organisation of Islamic Conference which reaffirms commitment to the U.N. Charter and fundamental human rights 'in the name of Allah' (Khadduri 1956; Moinuddin 1987; Ali and Rehman 2005; Baba 1994). The fact that radical clerics and terrorist groups reject those principles outright can hardly serve as a decisive argument in this debate.

\section{THE INHERENTLY 'VIOLENT' NATURE OF ISLAM: A FAILURE OF SCHOLARLY DEBATE OR SOMETHING ELSE?}

Given that Islam is not the only religion to have originally espoused the imperialistic discourse of the world (supra, Chapter 2.), that there is sufficient body of evidence to argue the influence of Islam on the principles underpinning International Law and order-or at least the significant overlapping between the two, and that this development has conveniently provided a platform for a more holistic interpretation of Islam (supra, Chapter 3.), the issue at hand is why the radical interpretation thereof-being preached by radical clerics, espoused tacitly or expressly by some Muslim governments and practiced by Al Qaida, ISIS and the slew of other terrorist groups-have found a fertile ground in the Middle East and beyond (Rollins 2011; Sedgwick 2004; McCants 2015). This phenomenon seems particularly perplexing, given the voluminous body of literature produced by Muslim scholars after September 11, 2001 which has sought to combat radicalisation. The answer to this question however appears to have less to do with the quality of academic debate about the genuine interpretation of Islam-although the quality thereof does play an important role in the overall efforts to 
refute radicalisation. Rather, a more plausible explanation for the still modest impact of these forward-looking views lies in the complex mixture of religion, culture, politics and history which has shaped the Middle East. This inter alia includes the precarious foundations of the ruling regimes in which politics and religion have been intrinsically inter-twined (Sharaby 1988); the lack of political and economic freedoms which renders the disfranchised population an easy pray for radical preaching (Pew Research Center 2011); the adverse impact of the protracted conflict between Israel and Palestinians (Ben-Naftali, Gross and Michaeli 2005); the sectarian division which throughout history has been successfully played out by local and foreign stakeholders - and which has only been exasperated by the US occupation of Iraq and the ensuing events which led to demise of a large part of the Middle East (Glen 2006); and the perceived shortcomings of efforts to integrate Muslims in the Western societies (Inglehart and Norris 2009). The precise implications of these and other pertinent developments on radical interpretation of Islam is difficult to fully grasp and probably merit country specific analyses (Shihade 2012). In order for this paper to modestly contribute to this debate though, the lack of legitimacy of the ruling regimes in the Middle East, which eventually led to the events commonly dubbed as the 'Arab Spring', merits particular consideration (Özekin and Akkaş 2014). It is important to note that the lack of political legitimacy does not necessarily imply the necessity for those regimes to give way to fully-fledged democratic governments, which would somehow instantly embrace a more holistic take on Islam. Such an approach would require a significant departure from the current political organisation of those states, the feasibility of which can only be determined on a case-by-case bases. Indeed, to suggest that the perceived lack of legitimacy can only be addressed by regime change would ignore one of the lessons learned from the Iraqi war as well as the Arab Spring: while countries in the region have much in common, their social and political fabric - as well as their prominence in international relations (Glen 2006) - differs to an extent which seems to render any attempt to offer universal political resolution for their predicaments ill-advised (Özekin and Akkaş 2014; Glaub 2012; Cox 2013). Instead, this paper draws on the empirical approach towards legitimacy which seeks to explain the willingness of citizens to comply or obey, rather than on the normative approach which tends to equate legitimate governments with democratic ones (Buttorff 2011). Thus the lack of legitimacy has to do with the general perception that most of the governments in the regionwhatever their source of power may be: dynastic families, sham or some sort of semi-free election, revolution or a military coup, have repeatedly failed to take meaningful steps in creating a more inclusive society and 
addressing the protracted injustice and inequality (Hourani 2013). The pervasive lack of government accountability led to building crony and corrupt societies with privileged few and large portions of population, youth and women in particular, excluded from political life and distribution of national wealth (UNDP 2016; Aksikas 2009). A research conducted by the Pew Research Center on May 1720011 revealed that $74 \%$ of the sampled Middle East population associated democracy with economic prosperity, rather than with free speech or free elections. The empirical data paint a bleak picture of the state of the play in the region: the Transparency International 2017 Corruption Perceptions Index reveals that five out of the ten perceived most corrupt countries in the world are from the Middle East region: Iraq, Libya, Sudan, Yemen and Syria; the 2017 Freedom House's Freedom of the World survey reveals that all countries in the Middle East fall within the category of 'not free' in terms of political rights and civil liberties; and the 2015 report of the International Labour Organization on youth unemployment reveals that the Middle East and North Africa regions continue to show by far the highest youth unemployment rates $-28.2 \%$ and $30.5 \%$, respectively

Despite the foregoing data, it is noteworthy that relatively small percent of Muslims seems to support terrorist activities in the name of Islam, although the situation varies from country to country. Thus a survey conducted in 2015 suggested that virtually all Muslims sampled in Beirut and $94 \%$ of those sampled in Jordan disapprove of ISIS; $91 \%$ of those sampled in Iraq and $92 \%$ in Indonesia thought that suicide bombings and other forms of violence against civilians were never or rarely justified, while in a few country a quarter or more of those sampled thought that acts of violence were at least sometimes justified, including $40 \%$ in the Palestinian territories, 39\% in Afghanistan, 29\% in Egypt and 26\% in Bangladesh, respectively (Poshter 2015). Nevertheless, this does not render the need to address a lack of social justice less urgent, as the precarious economic and social situation in the region will continue to provide the breeding ground for radicalisation and engaging in indiscriminate terrorist activities.

A case in point in this respect are Saudi Arabia and Egypt, two countries of a particular political and religious significance for the region which exemplify how the underlying problem of legitimacy plays into the hands of radical Islam, despite the appearance of somewhat different governing models between the two.

Saudi Arabia has been ruled by the Saudi family since its foundation (Al-Rasheed 2010), embraced a radical interpretation of Islam, Wahhabi, which was developed only in the XVIII century (Commins 2006; Bassiouni and Badr 2002) and forged an opaque alliance with the radical 
clerics which has provided an ideological platform for the Sunni terrorists groups in the region and beyond (Schanzer and Miller 2002).). Society is fractured and highly polarized, with women and youth being particularly disfranchised and deprived from opportunities to prosper. Human rights are severely restricted and often violated, other religious groups are not recognized while the other Muslim minority groups, including Shi'a, are discriminated against (Human Rights Watch 2018; Amnesty International 2017/2018). The government's failure to address social and economic problems has largely to do with theocratic political structure in which the principles of governance are derived from and subordinated to the strict interpretation of Islam. Such a structure inherently lacks an institutional framework conducive to plurality and peaceful reconciliation of various legitimate interests, let alone holding the government to account: the origins of the government are 'divine' and hence it cannot be challenged in any shape or form (Articles 5(b), 6-7 of the 1992 Basic Law of Governance of the Saudi Kingdom; Al-Rasheed 2010; Khadduri 1956; Cox 2013). Thus, rather than providing a lasting stability, the dogmatic organisation of the state renders it inherently unstable. Thus far the perceived structural challenges have been addressed by embarking on incremental social reforms. This includes allowing women, for the first time, to register to vote and run for office in the 2015 municipal elections, passing a new law permitting the establishment of civil society organizations, and creating the anti-corruption committee headed by the Crown Prince (Human Rights Watch 2016). In addition, the Royal Decree, issued on September 26, 2017 and effective June 2018 allows women to obtain a driving licence; the Kingdom was the only country in the world to ban women from driving. In 2016 the Crown introduced the 'Saudi Arabia Vision 2030', which is perceived as the most ambiguous reform plan to date (Ross 2016). Most recently, the Crown has taken a significant step to tackle Islamic extremism. By virtue of the Royal Decree of 20 October 2017 a council of scholars was set up to vet religious teachings around the world and combat fake and extremist religious texts on Islam. The significance of this step can hardly be overestimated: it presents nothing more than the official recognition of a country which was built on radical interpretation of Islam that a more forward looking interpretation thereof is possible - and indeed preferable, in keeping with overall social reforms.

Egypt, on the other hand, is markedly more secular state than Saudi Arabia. While the 2014 Constitution provides that Islam is the religion of the state and that the principles of Islamic Sharia are the principle source of legislation (Art. 2.), the Preamble of the Constitution ('Human dignity') also states: 
We believe in democracy as a path, a future, and a way of life; in political multiplicity; and in the peaceful transfer of power. We affirm the right of the people to make their future. They, alone, are the source of authority. Freedom, human dignity, and social justice are a right of every citizen...

In addition, women and religious minorities are protected by Constitution. Thus Article 11 provides that 'the state commits to achieving equality between women and men in all civil, political, economic, social, and cultural rights in accordance with the provisions of this Constitution'. Likewise, Article 3 provides that 'the principles of the laws of Egyptian Christians and Jews are the main source of laws regulating their personal status, religious affairs, and selection of spiritual leaders'. However, women remain discriminated in certain personal matters, including marriage, and are not offered sufficient protection against sexual and gender-based violence (Human Rights Watch 2016; Amnesty International 2017/2018).

Despite the progressive normative framework, Egypt has effectively been run by military since independence (Vatikiotis 2010). A majority of population, youth in particular, have had limited opportunity to participate in a political debate and share in the nation's wealth-despite the principles of social solidarity and equal opportunity being enshrined in the Constitution. In the 2017 Transparency International Corruption Perception Index, Egypt is ranked 117 out of 180 countries surveyed, The lack of government's legitimacy has traditionally been compensated by invoking the local form of pan-Arab nationalism (Vatikiotis 2010; Islami 2016; Hourany 2013), limiting human rights and pursuing overly harsh stance against political opposition, including the Muslim Brotherhood (Human Rights Watch 2016; Amnesty International 2017/2018). The most recent 2018 Human Rights Watch report reveals that human rights abuses have been markedly on rise. In May 2017 the new Law on Associations was introduced which is feared to eliminate the little remaining space for civil society and the work of human rights and other independent associations. The Law criminalizes the work of non-governmental organisations, providing for up to five-year prison terms for failing to adhere to its provisions such as operating or receiving funds without government approval.

These development in turn have created a political environment conducive to resorting to violence and proliferation of radical Islam (Row 2015). As a result, despite seemingly different governing models, the lack of legitimacy has rendered both Saudi Arabia and Egypt unstable, 
radicalised and unpredictable, with their future-and for that matter the future of the much of the Middle East, hanging in the balance.

This is the context in which the paroxysm and travesty of the radical jihad has been fully exposed. Originally set out to submit infidels to the rule of Islam, it gradually morphed into the indiscriminate killing of civilians-Muslims included. Indeed, the 2016 Global Terrorism Index (GTI) revealed that ten countries suffering the highest impact from terrorism as measured by the GTI in 2015 were Iraq, Afghanistan, Nigeria, Pakistan and Syria: they accounted for $72 \%$ of all deaths from terrorism in 2015 (Global Terrorism Index Report 2016). Likewise, the 2017 GTI report indicates that out of ten countries which most suffered from terrorism in 2016 (Iraq, Afghanistan, Nigeria, Syria, Pakistan, Yemen, Somalia, India and Turkey), nine were Muslim countries.

\section{CONCLUSION}

We set out to examine the relationship between Islam and international order against the background of its role in the development of International Law. This exercise served a broader purpose of supporting a discourse which showcases Islam as an inherent part of the common humanity shaping International Law and order, rather than an outlandish ideology. This proposition is being challenged by the hosts of factors, however, the lack of political legitimacy of the ruling regimes in the Middle East being one of them. The lack of legitimacy hampers efforts to embrace a more holistic understanding of Islam which would challenge the narrative of the besieged Muslim societies threatened by the alien values propagated by the West. While nurturing those prejudices might seem an opportunistic strategy for governments, in order to compensate for the lack of legitimacy, ultimately, this narrative only feeds into the agenda of the terrorist groups and other radical elements in Muslim societies, and thus pose a threat for the ruling regimes themselves. A more holistic approach towards Islam therefore would ostensibly facilitate governments' efforts to embark on necessary social reforms, in order to strengthen their own legitimacy and confront conservative elements which prefer the status quo: if the notion of universal humanity and dignity, which is embedded in International law and order, is reflective of the values underpinning Islam it is then incumbent on a government to commit to creating a more inclusive society which would further those values. It should be noted that a process of incremental reforms is already taking place in the Middle East, albeit in different shapes and forms, and with varying levels of success (Anoushiravan and Wright 2008; Salameh and Ali Ananzah 2015; 
Human Rights Watch 2018a). Given the protracted delay in addressing the structural problems and the conflicting regional and foreign interests, however, the odds are stacked against those reforms. Nevertheless, the only riskier policy option for the government to pursue is trying to maintain the illusive status quo. The failure of the ruling elites to comprehend this dynamic will inevitably result in more instability and radicalisation. This in turn would have far-reaching adverse consequences on the understanding and practicing of Islam.

\section{REZIME \\ UTICAJ ISLAMA NA MEĐUNARODNO PRAVO: RAZLIČITA TUMAČENJA I NJIHOVE IMPLIKACIJE}

U ovom radu se proučava odnos između Islama i savremenog međunarodnog poretka. Ovaj odnos se proučava u kontekstu navodno pozitivnog uticaja Islama na formulisanje osnovnih principa Međunarodnog prava, sa ciljem da se identifikuju razlozi zbog čega pozivi na radikalni džihad, koji smatraju da Islam nije kompatibilan sa savremenim međunarodnim poretkom, ipak imaju odjeka na Bliskom Istoku i drugim zemljama sa muslimanskim stanovništvom. U radu se ističe da ovaj fenomen nema svoje uzroke u kvalitetu naučne i akademske rasprave o pravoj prirodi Islama, iako ova rasprava svakako doprinosi ukupnim naporima da se suzbije radikalizacija Islama. Međutim, uzroke radikalizacije Islama treba tražiti u kompleksnom nasleđu zemalja Bliskog Istoka, uključujući nedostatak političkog legitimiteta vladajućih režima u zemljama ovog regiona. U radu se prvo analiziraju pravila koja uređuju pitanja rata i mira u Islamu. Nakon toga, analizira se u kojoj su meri ova pravaila uticala na osnovne principe na kojima se zasniva Međunarodno pravo. Nakon toga, u radu se analizira uticaj nedostatka političkog legitimiteta vladajućih režima na Bliskom Istoku na proces radikalizacije Islama. U poslednjem delu rada daje se sumarni pregled osnovnih zaključaka istraživanja.

Ključne reči: Islam, Međunarodno pravo, međunarodni poredak, radikalni džihad, politički legitimitet 


\section{REFERENCES}

1. Ahmad, Muhammad Idress (2014) The Road to Iraq: The Making of a Neoconservatives War, Edinburgh University Press.

2. Aksikas, Jaafar (2009) Arab Modernities: Islamism, Nationalism, and Liberalism in the Post-Colonial Arab World, Peter Lang Publishing, Inc.

3. Amnesty International (2017/2018), Annual Report, available at https://www.amnesty.org/en/latest/research/2018/02/annual-report201718.

4. Ali, M.S (2004) The Holly Qur'an, Islam International Publications Limited.

5. Ali, Norfadhilah Mohd et al (2011) 'When Civilians Cross the Line: The International and Islamic Law Perspective', International Journal of Humanities and Social Science Vol. 1 No. 21: 224-231.

6. Ali, Shaheen Sardar (2010) 'Resurrecting Siyar through Fatwas? (Re)constructing Islamic International Law in Post (Iraq)-Invasion World' in Foblets, M.C. and Carlie, J. Y. (ed.) Islam and Europe, Crises are Challenges, Leuven University Press.

7. Ali, Shaheen Sardar and Rehman, Javaid (2005) 'The Concept of Jihad in Islamic International Law'. Journal of Conflict \& Security Law, Vol. 10 No. 3: 321-343.

8. Al-Rasheed, Madawi (2010) A History of Saudi Arabia, Cambridge University Press.

9. Al-Zuhili, Wahbeh Sheikh (2005) 'Islam and International Law'. International Review of the Red Cross, Volume 87, No. 858: 269-283.

10. Anoushiravan, Ehteshami, Wright M. Steven (2008), Reform in the Middle East Oil Monarchies, Ithaca Press.

11. Asseburg, Muriel (2017) Protest, Revolt and Regime Change in the Arab World, SWP Research Paper, Berlin.

12. Baba, Noor Ahmad (1994) Organisation of Islamic Conference: Theory and Practice of Pan-Islamic Cooperation, Oxford University Press.

13. Badr, Gamal M. (1982) A Survey of Islamic International Law, Proceedings of the $76^{\text {th }}$ Annual Meeting of the American Society of International Law: 56-61.

14. Barnidge, Robert P. Jr (2010) 'Islam and International Humanitarian Law: A Question of Compatibility?'. Israeli Year Book on Human Rights.

15. Bassiouni, Cherif and Badr, Gamal M. (2002) 'The Shari'ah: Sources, Interpretation, and Rule Making'. 1 UCLA Journal of Islamic and Near Eastern Law, Vol. 1, Issue 2: 135-182. 
16. Bassiouni, M. Cherif (2007) 'Evolving Approaches to Jihad: From Self-Defence to Revolutionary and Regime-Change Political Violence', Chicago Journal of International Law, Vol. 11, Issue 1: 138.

17. Ben-Naftali, Orna, Gross, Aeyal M. and Michaeli, Keren (2005) 'Illegal Occupation: Framing the Occupied Palestinian Territory'. Berkeley Journal of International Law, Vol. 23, Issue 3: 551-614.

18. Bennoune, Karima (1994) 'As Salamy Alaykum? Humanitarian Law in Islamic Jurisprudence'. Michigan Journal of International Law. Vol. 15. Issue 2: 605-644.

19. Bluntschli, Johann Kaspar (2000) The Theory of the State, Kitchener: Batoche Books.

20. Boisard, A. Marcel A (1980) 'On the Probable Influence of Islam on Western Public and International Law'. International Journal of Middle East Studies, Vol. 11, Issue 4: 429-450.

21. Bouzenita, Anke Iman (2007) 'The Siyar - An Islamic Law of Nations?'. Asian Journal of Social Sciences, Vol. 35, Issue 1: 19-46.

22. Buttorff, Gail Jeanne (2011) Legitimacy and the politics of opposition in the Middle East and North Africa, University of Iowa (P.H.D. thesis), available at http://ir.uiowa.edu/cgi/viewcontent.cgi?article=2510\&context=etd.

23. Charter of the Organization of Islamic Conference (1972), available at https://www.oic-oci.org/page/?p_id=53\&p_ref=27\&lan=en

24. Charter of the United Nations (1945), available at https://treaties.un.org/doc/publication/ctc/uncharter.pdf.

25. Cockayne, James (2002) 'Islam and international humanitarian law: From a clash to a conversation between civilizations', International Review of the Red Cross, Vol. 84, No. 847: 597-626.

26. Commins, David (2006) The Wahhabi Mission and Saudi Arabia, L.B. Tauris.

27. Cox, Neville (2013) 'The Clash of Unprovable UniversalismsInternational Human Rights and Islamic Law', Oxford Journal of Law and Religion, Vol. 2, No. 2: 307-329.

28. Draper, G.I.A.D. (1965) 'The Interaction of Christianity and Chivalry in the Historical Development of the Law of War'. International Review of Red Cross, Vol. 5, Issue 46: 3-23.

29. Freedom House (2017) Freedom in the World, available at https://freedomhouse.org/report/freedom-world/freedom-world-2017

30. Glaub, Florence (2012) 'Understanding Instability: Lessons for the Arab Spring', AHRC Public Policy Series No 9. 
31. Glen, Rangwala (2006) 'Critical Commentary: The Assumption of Democracy', The Cambridge Review of International Affairs, Vol. 19, No. 2: 299-308.

32. Hamidullah, Mohammad (2001) Islamic Worlds: Inter-state Relations, Anmol Publications.

33. Hourani, Albert (2013) A History of the Arab Peoples, Faber and Faber.

34. Human Rights Watch (2016), World Report, available at https://www.hrw.org/world-report/2016.

35. Human Rights Watch (2018), World Report, available at https://www.hrw.org/world-report/2018.

36. Human Rights Watch (2018a) Top five reforms Middle East governments can make in 2018, available at https://www.hrw.org/news/2018/01/18/top-5-reforms-middle-eastgovernments-can-make-2018.

37. Huntington, P. Samuel (1996) The Clash of Civilizations and the Remaking of World Order, Simon and Schuster.

38. Hurd, Elizabeth Shakman (2003) Appropriating Islam: The Islamic Other in the Consolidation of Western Modernity, Critique: Critical Middle Eastern Studies, Spring: 25-41.

39. Ibn al Hassan al-Shaybani, Muhammad (1998) The Shorter Book of Muslim International Law: edited, translated and annotated by Mahmood Ahmad Ghazi. Islamic Research Institute: Islamabad [Ghazi, Introduction to the Shorter Book of Muslim International Law].

40. Ibn Khaldun, Zahid (2015) The Muqaddimah: An Introduction to History. The Classic Islamic History of the World (translated and introduced by Franz Rosenthal), Princeton University Press.

41. Institute for Economics and Peace (2016) (2018) Global Terrorism Index Report - GTI, available at http://globalterrorismindex.org

42. International Court of Justice (1996), 'Legality of the Threat or Use of Nuclear Weapons', Advisory Opinion, 1. C.J. Reports, available at http://www.icj-cij.org/files/case-related/95/095-19960708-ADV-0100-EN.pdf

43. International Labour Organization - ILO (2015) Global Employment Trends for Youth, available at http://www.ilo.org/wcmsp5/groups/public/---dgreports/---dcomm/--publ/documents/publication/wcms_412015.pdf

44. Islami, Islam (2016) 'Political History of Modern Egypt', Iliria International Review, Vol. 6. No. 1: 189-206.

45. Jennings, Robert, Arthur Watts (1992), Oppenhaim's International Law, $9^{\text {th }}$ edition, Longman Group U.K. Limited, Vol. 1, 
46. Jankins, Mark W. (ed.) (1991) The influence of religion on the development of international Law, Springer.

47. Kamali, Mohammad Hashim, (2003) Principles of Islamic Jurisprudence, Cambridge Islamic Texts Society.

48. Khadduri, Majid (1956) 'Islam and the Modern Law of Nations', American Journal of International Law, Vol. 50, Issue 2: 358-372.

49. Lipka, Michael (2017) Muslims and Islam: key findings in the U.S and around the world, Pew Research Centre. Available at http://www.pewresearch.org/fact-tank/2017/08/09/muslims-and-islamkey-findings-in-the-u-s-and-around-the-world/

50. Makdisi, Georg (1979) 'Sunnis School of Law in Islamic Religious History'. International Journal of Middle East Studies, Vol. 10, Issue 1: $1-8$.

51. Marboe, Irgmand (2013) 'Promoting the Rule of Law: UN, OIC and ILA Initiatives Approaching Islamic Law' in Muller A. T. Islam and International Law, Engaging Self-Centrism from a Plurality of Perspectives, Leiden.

52. McCants, William (2015) The ISIS Apocalypse, McMillan Publishers.

53. Moinuddin, Hasan (1987) The Charter of the Islamic Conference and Legal Framework of Economic Co-operation among its Member States. Oxford: Clarendon Press.

54. Moschtaghi, R. (2009) 'The Relationship between International Law, Islamic Law and Constitutional Law of the Islamic Republic of Iran A Multilayer System of Conflict?'in Bogdandy von A (ed.) Marx Planck Year Book of the United Nations, 375-420.

55. Muasher, Marwan (2014) The Second Arab Awakening and the Battle for Pluralism. Yale University Press.

56. Munir, Muhammad (2007) 'Islamic International Law (Siyar): Introduction', Human Rights Conflict Prevention Centre, Vol. 7, No. 1-2: 923-940.

57. Mushkat, Roda (1987) "Is War Ever Justifiable? A Comparative Survey". Loyola of Los Angeles International and Comparative Law Journal, Volume 9, Issue 2: 227-317.

58. Özekin, Muhammed Kürşad and Akkaş, Hasan Hüseyin (2014) "An Empirical Look To The Arab Spring: Causes And Consequences". Turkish Journal of International Relations, Vol. 13, No. 1-2: 76-87.

59. Pew Research Center (2011) Democracy and the role of Islam, available at www.pewglobal.org/2011/05/17/arab-spring-fails-toimprove-us-image/4/\#chapter-3-views-of-democracy-and-the-role-ofislam

60. Phillips, Jonathan (2008) The Second Crusade: Extending the Frontiers of Christendom. Yale University Press. 
61. Philpott, Daniel (2007) 'Explaining the Political Ambivalence of Religion', American Political Science Review, Vol. 101, Issue 3: 505525.

62. Poshter, Jacoub (2015) In Nations with Significant Muslim Population Much Disdain for ISIS, Pew Research Center, November 2015, available at http://www.pewresearch.org/fact-tank/2015/11/17/innations-with-significant-muslim-populations-much-disdain-for-isis/

63. Rollins, John (2011) 'Al Qaeda and Affiliates: Historical Perspective, Global Presence, and Implications for U.S. Policy', Congressional Research Centre, 25 January 2011, available at https://fas.org/sgp/crs/terror/R41070.pdf

64. Ross, Denis (2016) 'In Saudi Arabia, a revolution disguised as reform', Washington Post, 8 September 2016, available at

https://www.washingtonpost.com/opinions/global-opinions/in-saudiarabia-a-revolution-disguised-as-reform/2016/09/08/979f03f6-752611e6-b786-19d0cb1ed06c_story.html?utm_term=.3c80b481db03

65. Row, Bedford (2015) The History of the Muslim Brotherhood. London.

66. Sachedina, Abdulaziz (2007) 'The Clash of Universalisms: Religious and Secular in Human Rights', The Hedgehog Review. Fall 2007, posted on 27 October 2007, available at http://consciencelaws.org/blog/?p=2617

67. Said, W. Edward (2003) Preface to the Twenty-Fifth Anniversary Edition, Orientalism, Vintage.

68. Salameh Torki Ban Mohammed and Ali Ananzah Azzam (2015) 'Constitutional Reforms in Jordan: A Critical Analyses', DOMES, Digest of Middle East Studies, Volume 24, Issue 2: 139-160.

69. Sardar, Ziaudin (2015) Reading the Qur'an, Hurst \& Co Publishers Ltd.

70. Schanzer, Jonathan and Miller, Steven (2002) Facebook Fatwa: Saudi Clerics, Wahhabi Islam, and Social Media, FDD Press.

71. Sedgwick, Mark (2004) 'Al Qaeda and the Nature of Religious Terrorism', Journal of Terrorism and Political Violence, Vol. 16, Issue 4: 795-814.

72. Sharaby, Hisham (1988) Neopatriarchy: A Theory of Distorted Change in Arab Society, Oxford University Press.

73. Shihade, Magid (2012) 'On the Difficulty in Predicting and Understanding the Arab Spring: Orientalism, Euro-Centrism, and Modernity', International Journal of Peace Studies, Volume 17, No. 2: 57-70. 
74. Stumpf, A. Cristoph (2005) 'Christian and Islamic Traditions of Public International Law', Journal of the History of International Law, Volume 7, Issue 1: 69-80.

75. Transparency International (2016) People and Corruption, Middle East and North Africa Survey, available at https://www.transparency.org/whatwedo/publication/people_and_corr uption_mena_survey_2016

76. Transparency International (2017) Corruption Perception Index Annual Report, available at https://www.transparency.org/news/pressrelease/corruption_perceptio ns_index_2017_shows_high_corruption_burden_in_more_than

77. Vatikiotis, J. Panayiotis (2010) The History of Modern Egypt: From Muhammad Ali to Mubarak. John Hopkins University Press.

78. Westbrook, David (1992-1993) 'Islamic Law and Public International Law: Separate Expressions of World Order', Virginia Journal of International Law, Vol. 33:819-897.

79. Yousaf, Omar (2012) 'IHL' as Islamic Humanitarian Law: A Comparative Analysis of International Humanitarian Law \& Islamic Military Jurisprudence Amidst Changing Historical Contexts', Florida Journal of International Law, Vol. 24, No. 2: 439-468.

80. United Nation Development Program-UNDP (2011) Arab Development Challenges Report, available at http://www.undp.org/content/dam/undp/library/corporate/HDR/UNDP -ADCR_En-2012.pdf.

81. UNDP (2016) Arab Human Development Report: Youth and the Prospects for Human Development in a Changing Reality, available at http://www.arab-hdr.org/reports/2016/english/AHDR2016En.pdf

82. Zahid, Muhammad Anowar and Shapiee, Rohimi (2010) 'Customs As a Source of Siyar and International Law: A Comparison of the Qualifying Criteria', International Journal of Civil Society Law, Vol. VIII, Issue 1: 36-55.

Ovaj rad je primljen 27.09.2018., a na sastanku redakcije časopisa prihvaćen za štampu 22.11.2018. godine. 